\title{
PHENOTYPIC CHARACTERISTICS OF INDIGENOUS SHEEP OF BANGLADESH
}

\author{
S. Pervage ${ }^{1}$, M. Ershaduzzaman ${ }^{1}$, M. A. I. Talukder ${ }^{1}$, M. N. Hasan ${ }^{1}$ and \\ M. A. M. Y. Khandoker ${ }^{2}$
}

\begin{abstract}
This experiment was undertaken to know the phenotypic characteristics of native sheep. The study was conducted to investigate morphometric characters of sheep in three different field sites (Naogaon, Noakhali and Tangail) and Bangladesh Livestock Research Institute (BLRI) nucleus flock through close observation, measuring and record keeping. Characteristics of body weight, body length, heart girth, wither height, fore leg length, hind leg length, head length, ear length, ear width, horn length etc were collected from mature sheep. The results indicate that the average litter size, birth weight, weaning weight and body weight gain were comparatively higher in sheep of BLRI nucleus flock than those of other three regions. The average numbers of service/conception, post partum heat period (days), age at first heat (days), age at first lambing (days), lambing interval (days) were $1.30,34.13,266.50,432.72,192.17$ respectively in BLRI nucleus flock which were comparatively better than the other three regions. The average litter size, birth weight $(\mathrm{kg})$, weaning weight $(\mathrm{kg})$ and body weight gain $(\mathrm{g})$ in nucleus flock were $1.80,1.19,6.74$ and 60.70 consequently. The overall performance of the sheep of BLRI nucleus flock were comparatively better than the others which may be due to the result of selective breeding, improve feeding, housing, health management etc.
\end{abstract}

Key words: Bangladeshi indigenous sheep, Phenotypic characters

\section{Introduction}

The phenotype is a result of both genotype and the environment. The animal phenotypes of interest can be divided into three main categories: 1) physical description or measurements; 2) performance characteristics; and 3) adaptation to the environment. Physical characteristics include such characteristics as presence or absence of horns, coat color, body length, wither height, heart girth, tail length, tail type, fur type (wool versus hair) etc. Some of these like presence or absence of horns have simple Mendelian inheritance and have been studied extensively, at least in temperate livestock.

Others such as withers height, heart girth and body length are obviously quantitative in nature. Physical characteristics are arguably the most commonly used criteria for breed

${ }^{1}$ Goat and Sheep Production Research Division, Bangladesh Livestock Research Institute, Savar, Dhaka-1341, Bangladesh

2 Department of Animal Breeding and Genetics, Bangladesh Agricultural University, Mymensingh-2202

(Received: September 09, 2009) 
or strain definitions. For this reason, attempts have been made to investigate these traits to characterize the populations. One such example is the classification of sheep populations based on multivariate analyses of physical characteristics. Henson (1992) suggested that improvement of local breeds through selective breeding can be superimposed on and be an integral part of conservation programs. Performance characteristics are the traits most familiar to animal breeders. In mainstream, 'Westerntype' animal production, they tend to be limited to such traits as milk yield and quality, meat characteristics (measures of growth and carcass quality) and wool production (fleece yield and quality). They also include reproductive traits (age at first parturition, calving interval, prolificacy etc.). Indeed, in these systems there is no distinction between performance and adaptive traits. Not much thought has gone into south-east Asia and sometimes the animals are unfairly condemned for under-performing, when indeed the whole picture has not been taken into account. As a result, breeding strategies for tropical low and medium input systems, which generally subsistence oriented, do not exist. Therefore, the objectives of the research program are to set determine the morphological characteristics, productive and reproductive performance of native sheep under semi-intensive and field management conditions.

\section{Materials and Methods}

Field data on sheep under study were collected from three agro-ecological locations namely Jamuna river basin area, Barind area and Coastal area and also BIRI for conservation, characterization and the entire management strategies were designed to collect the maximum amount of data on the dam, sire and lambs. In field condition, most of the houses of sheep were made of tin sheds and the walls were with soil. Animals were allowed to graze for 8-10 hours per day and reared by tethering as well as traditional system (extensive) without any feed supplementation. In Bangladesh Livestock Research Institute (BLRI) sheep farm, all the animals were reared by semiintensive system and housed in slatted floor permanent house. Rams were always kept separately from ewes to avoid unplanned mating. Animals were allowed to graze for 7-8 hours per day. Concentrate feed was offered twice daily at the rate of $300 \mathrm{~g}$ per head per day. The data were recorded on morphologica1 characteristics and reproductive performance of sheep conducted in three districts (Tangail, Noakhali \& Naogaon) and BLRI regularly. The morphometric characteristics of both sexes were measured using the weighing balance and a standard measuring tape.

Parameters studied for physical and reproductive traits were; coat color, body weight $(B W)$, body length $(B L)$, heart girth $(H G)$, wither height $(W H)$, fore leg length $(F L L)$, hind leg length (HLL), horn length ( $H n L)$, ear length (EL), age at first heat (AFH), age at first lambing (AFL), lambing interval (LI), post partum heat period (PPHP), gestation length (GL), number of service/conception (NSC), litter size (LS), post lambing ewe weight (PLEW), lamb birth weight (LBW), weaning weight (WW), body weight gain (BWG) and wool production. The statistical analysis of the data was performed using ANOVA 
procedure of SPSS (Statistical Packages for Social Sciences, Version 11.5). The difference among the treatment means were examined by using Duncan's Multiple Range Test.

\section{Results and Discussion}

The coat colors of sheep in Jamuna region were either whitish, brown, blackish-red and black and white mixed; the same as Barind were white, blackish brown or mixed and the Coastal region then were mostly white or light to deep brown.

The morphological characteristics of rams are shown in Table 1. The regions had significant $(P<0.01)$ effect on BW, BL, HG, WH, HL, EL, EW, and HnL. The rams of BLRI farm were found to be better than that of Coastal, Barind and Jamuna regions in respect to BW, BL and HG. The regions had non-significant effect on FLL and HLL.

Table 1. Morphological characteristics of Rams (1-4 years of age)

\begin{tabular}{|c|c|c|c|c|c|}
\hline \multirow{2}{*}{ Parameters } & \multicolumn{4}{|c|}{ Regions } & \multirow{2}{*}{ Probability } \\
\hline & BLRI (25) & Jamuna (20) & Barind (18) & Coastal (17) & \\
\hline \multirow[t]{2}{*}{ Body Weight (kg) } & $25.83^{\mathrm{a}}$ & $18.04^{b}$ & $19.10^{\mathrm{b}}$ & $23.64^{\mathrm{a}}$ & $P<0.001$ \\
\hline & \pm 0.99 & \pm 0.44 & \pm 0.80 & \pm 0.75 & \\
\hline \multirow[t]{2}{*}{ Body Length (cm) } & $73.60^{\mathrm{a}}$ & $64.42^{\mathrm{b}}$ & $65.70^{b}$ & $67.60^{\mathrm{b}}$ & $P<0.01$ \\
\hline & \pm 1.96 & \pm 1.32 & \pm 1.13 & \pm 2.62 & \\
\hline \multirow[t]{2}{*}{ Heart Girth (cm) } & $67.73^{\mathrm{a}}$ & $58.57^{\mathrm{b}}$ & $60.20^{\mathrm{b}}$ & $67.50^{\mathrm{a}}$ & $P<0.01$ \\
\hline & \pm 2.41 & \pm 1.37 & \pm 1.48 & \pm 2.28 & \\
\hline \multirow[t]{2}{*}{ Wither Height (cm) } & $52.33^{\mathrm{ab}}$ & $47.71^{\mathrm{b}}$ & $48.50^{b}$ & $56.30^{\mathrm{a}}$ & $P<0.01$ \\
\hline & \pm 1.93 & \pm 0.80 & \pm 1.06 & \pm 1.63 & \\
\hline \multirow[t]{2}{*}{ Fore Leg Length (cm) } & 30.53 & 29.28 & 27.90 & 30.70 & NS \\
\hline & \pm 0.99 & \pm 0.52 & \pm 0.99 & \pm 1.50 & \\
\hline \multirow[t]{2}{*}{ Hind Leg Length (cm) } & 34.80 & 33.71 & 32.20 & 34.30 & NS \\
\hline & \pm 1.16 & \pm 0.71 & \pm 1.14 & \pm 1.67 & \\
\hline \multirow[t]{2}{*}{ Head Length (cm) } & $24.66^{a}$ & $20.85^{b}$ & $19.75^{\mathrm{b}}$ & $25.20^{\mathrm{a}}$ & $P<0.01$ \\
\hline & \pm 1.16 & \pm 1.37 & \pm 0.75 & \pm 1.44 & \\
\hline \multirow[t]{2}{*}{ Ear Length (cm) } & $9.60^{b}$ & $8.28^{b}$ & $6.40^{\mathrm{C}}$ & $11.40^{\mathrm{a}}$ & $P<0.001$ \\
\hline & \pm 0.37 & \pm 0.60 & \pm 0.81 & \pm 0.28 & \\
\hline \multirow[t]{2}{*}{ Ear Width $(\mathrm{cm})$} & $5.66^{\mathrm{a}}$ & $5.85^{a}$ & $4.55^{b}$ & $6.45^{\mathrm{a}}$ & $P<0.01$ \\
\hline & \pm 0.35 & \pm 0.26 & \pm 0.29 & \pm 0.25 & \\
\hline \multirow[t]{2}{*}{ Horn Length (cm) } & $11.26^{\mathrm{ab}}$ & $3.42^{c}$ & $7.50^{\mathrm{bc}}$ & $13.50^{\mathrm{a}}$ & $P<0.001$ \\
\hline & \pm 1.70 & \pm 0.20 & \pm 1.80 & \pm 0.83 & \\
\hline
\end{tabular}

${ }_{a, b, c}$ Means within rows with different superscripts differ significantly

${ }^{*}$ Figure in parentheses indicates the total number of observations

The morphological characteristics of ewes are given in Table 2. The regions had significant $(P<0.01)$ effect on $B W, B L, H G, W H, H L, E L$ and EW. The BW, HG and WH of ewes were significantly $(P<0.01)$ higher in BLRI than Coastal, Jamuna and Barind 
Bang. J. Anim. Sci. 2009, 38(1\&2)

regions. This may be due to differences in genetic make up, feeding, housing, health and management factors.

Table 2. Morphological characteristics of Ewes (1-4 years of age)

\begin{tabular}{|c|c|c|c|c|c|}
\hline \multirow{2}{*}{ Parameters } & \multicolumn{4}{|c|}{ Regions } & \multirow{2}{*}{ Probability } \\
\hline & BLRI (41) & Jamuna (38) & Barind (42) & Coastal (40) & \\
\hline Body Weight (kg) & $19.20^{\mathrm{a}} \pm 0.35$ & $16.52^{C} \pm 0.30$ & $15.25^{d} \pm 0.49$ & $17.93^{b} \pm 0.24$ & $P<0.001$ \\
\hline Body Length (cm) & $65.96^{a} \pm 0.76$ & $62.67^{b} \pm 0.87$ & $62.20^{b} \pm 1.09$ & $63.48^{b} \pm 0.56$ & $P<0.01$ \\
\hline Heart Girth (cm) & $64.12^{a} \pm 0.79$ & $57.10^{C} \pm 0.93$ & $57.31^{\mathrm{C}} \pm 1.15$ & $60.05^{b} \pm 0.62$ & $P<0.001$ \\
\hline Wither Height (cm) & $51.16^{a} \pm 0.49$ & $49.03^{b} \pm 0.49$ & $46.03^{C} \pm 0.89$ & $51.11^{a} \pm 0.67$ & .001 \\
\hline Fore Leg Length $(\mathrm{cm})$ & $35.19 \pm 0.30$ & $28.32 \pm 0.30$ & $27.34 \pm 0.38$ & $28.97 \pm 0$ & NS \\
\hline Hind Leg Length (cm) & $34.38 \pm 0.27$ & $32.71 \pm 0.34$ & $31.03 \pm 0.53$ & $31.65 \pm 0.38$ & NS \\
\hline Head Length $(\mathrm{cm})$ & $22.03^{\mathrm{a}} \pm 0.34$ & $19.21^{\mathrm{c}} \pm 0.27$ & $19.58^{C} \pm 0.36$ & $20.42^{b} \pm 0.19$ & $P<0.001$ \\
\hline Ear Length $(\mathrm{cm})$ & $9.37^{b} \pm 0.37$ & $8.96^{b} \pm 0.40$ & $6.06^{\mathrm{c}} \pm 0.46$ & $11.85^{\mathrm{a}} \pm 0.11$ & $P<0.001$ \\
\hline Ear Width $(\mathrm{cm})$ & $5.77^{\mathrm{a}} \pm 0.16$ & $6.10^{a} \pm 0.22$ & $4.70^{\mathrm{b}} \pm 0.21$ & $6.02^{a} \pm 0.07$ & $P<0.001$ \\
\hline
\end{tabular}

${ }^{\text {abcd }}$ Means within rows with different superscripts differ significantly

* Figure in parentheses indicates the total number of observations

The average wool production in BLRI, Jamuna, Barind and coastal region sheep were 267.05, 268.35, 321.33 and 531.56g/annum/animal/cutting (Fig. 1). Woolliams et al. (1998) showed that genetic improvement of the indigenous non-descript animals through selective breeding could be an easier option. This technique might be suitable for development of a wool producing breed.

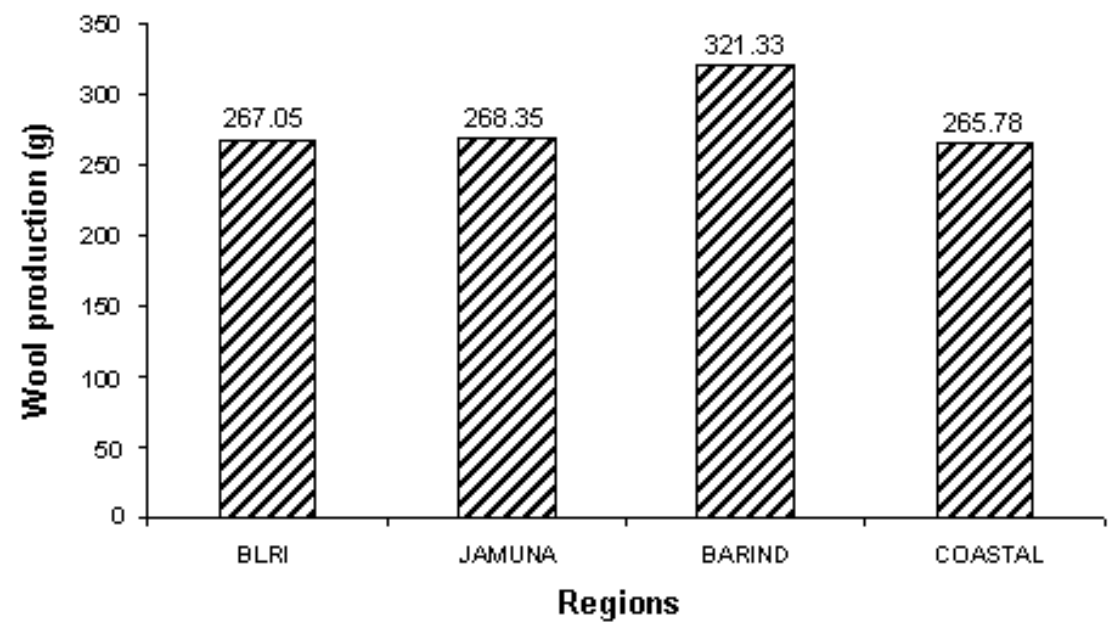

Fig. 1. Wool production in different region sheep

Maijala et al. (1977) found age at first lambing to be13-16 months, lambing interval to be 6-8 months, litter size to be 2.0 of Hu-yang sheep in China which was almost similar with the performance of Bengal sheep. The reproductive performances of native sheep 
are shown in Table 3 . The regions had significant $(P<0.01)$ effect on PLEW, female lamb birth weight, PPHP, WW, BWG, AFH, AFL and LI. The female lamb birth weight, WW, BWG and PLEW were significantly better $(P<0.01)$ in sheep of BLRI than those of Coastal, Barind and Jamuna regions. The average wool production (g/animal/cutting/ year) were comparatively higher in Barind region than the others (Fig. 1). The average PPHP, AFH, AFL and LI were significantly $(P<0.01)$ shorter in sheep of BLRI followed by Barind, Jamuna and Coastal regions. Lambs were heavier at birth, grew faster than lighter weight lambs which also supports the results of Geenty et al. (1982). The average gestation length ranges from 147 to 151 days which also supports the previous results of Rusyad et al. (1985) where they found the gestation length 147.5 and 149.9 days for Priangan sheep in Indonesia. The overall performance of BLRI sheep were better among the other three regions which might be due to the better management, feeding and selective breeding. Turner (1978) reported that using selection technique the litter size of one Australian Merino flock has been increased from about 1.1 to 2.1 in about 25 years of selection.

Table 3. Productive and Reproductive Performance of Native Sheep

\begin{tabular}{|c|c|c|c|c|c|}
\hline \multirow{2}{*}{ Parameters } & \multicolumn{4}{|c|}{ Regions } & \multirow{2}{*}{ Probability } \\
\hline & BLRI & Jamuna & Barind & Coastal & \\
\hline \multirow[t]{2}{*}{ No. of service/conception } & 1.30 & 1.47 & 1.52 & 1.44 & NS \\
\hline & $\pm 0.09(36)$ & $\pm 0.12(17)$ & $\pm 0.11(21)$ & $\pm 0.12(18)$ & \\
\hline \multirow[t]{2}{*}{ Gestation length (days) } & 147.83 & 151.46 & 150.33 & 149.57 & NS \\
\hline & $\pm 0.89(26)$ & $\pm 1.29(13)$ & $\pm 1.28(12)$ & $\pm 1.12(14)$ & \\
\hline \multirow[t]{2}{*}{ Litter size } & 1.80 & 1.70 & 1.58 & 1.56 & NS \\
\hline & $\pm 0.13(36)$ & $\pm 0.14(20)$ & $\pm 0.11(31)$ & $\pm 0.13(30)$ & \\
\hline \multirow[t]{2}{*}{ Post lambing ewe weight $(\mathrm{kg})$} & $17.19^{b}$ & $14.77^{\mathrm{c}}$ & $15.45^{\mathrm{c}}$ & $18.77^{\mathrm{a}}$ & $P<0.001$ \\
\hline & $\pm 0.31(36)$ & $\pm 0.49(20)$ & $\pm 0.50(31)$ & $\pm 0.41(20)$ & \\
\hline \multirow[t]{2}{*}{ Birth weight $(\mathrm{kg})$ Male } & 1.36 & 1.34 & 1.33 & 1.50 & NS \\
\hline & $\pm 0.07(33)$ & $\pm 0.07(20)$ & $\pm 0.05(25)$ & $\pm 0.05(30)$ & \\
\hline \multirow[t]{2}{*}{ Female } & $1.19^{\mathrm{ab}}$ & $1.09^{\mathrm{b}}$ & $1.28^{\mathrm{a}}$ & $1.07^{\mathrm{b}}$ & $P<0.01$ \\
\hline & $\pm 0.04(31)$ & $\pm 0.04(20)$ & $\pm 0.06(25)$ & $\pm 0.03(30)$ & \\
\hline \multirow[t]{2}{*}{ Post partum heat period (days) } & $34.13^{\mathrm{a}}$ & $39.14^{\mathrm{b}}$ & $41.30^{\mathrm{b}}$ & $43.12^{b}$ & $P<0.01$ \\
\hline & $\pm 0.67(30)$ & $\pm 1.26(20)$ & $\pm 0.96(24)$ & $\pm 1.13(25)$ & \\
\hline \multirow[t]{2}{*}{ Weaning weight $(\mathrm{kg})$} & $6.74^{\mathrm{a}}$ & $5.74^{b}$ & $5.70^{\mathrm{b}}$ & $5.89^{\mathrm{ab}}$ & $P<0.05$ \\
\hline & $\pm 0.28(36)$ & $\pm 0.30(14)$ & $\pm 0.21(19)$ & $\pm 0.20(17)$ & \\
\hline \multirow[t]{2}{*}{ Body weight gain (g/day) } & $60.70^{\mathrm{a}}$ & $50.19^{b}$ & $49.18^{\mathrm{b}}$ & $51.21^{\mathrm{ab}}$ & $P<0.05$ \\
\hline & $\pm 3.08(36)$ & $\pm 3.33(14)$ & $\pm 2.70(19)$ & $\pm 2.21(17)$ & \\
\hline \multirow[t]{2}{*}{ Age at first heat (days) } & $266.50^{\mathrm{a}}$ & $333.17^{b}$ & $329.00^{\mathrm{b}}$ & $341.23^{\mathrm{b}}$ & $P<0.001$ \\
\hline & $\pm 4.77(36)$ & $\pm 4.64(11)$ & $\pm 4.6(17)$ & $\pm 5.05(13)$ & \\
\hline \multirow[t]{2}{*}{ Age at first lambing (days) } & $432.72^{\mathrm{a}}$ & $491.92^{b}$ & $488.09^{b}$ & $499.92^{b}$ & $P<0.001$ \\
\hline & $\pm 5.54(30)$ & $\pm 6.26(17)$ & $\pm 5.59(20)$ & $\pm 5.78(23)$ & \\
\hline \multirow[t]{2}{*}{ Lambing interval (days) } & $192.17^{\mathrm{a}}$ & $221.13^{\mathrm{b}}$ & $228.57^{b}$ & $214.32^{b}$ & $P<0.01$ \\
\hline & $\pm 4.36(30)$ & $\pm 4.97(22)$ & $\pm 5.34(20)$ & $\pm 4.63(24)$ & \\
\hline
\end{tabular}

${ }^{\mathrm{abc}}$ Means within rows with different superscripts differ significantly $(P<0.001, P<0.01$ to $P<0.05)$

${ }^{*}$ Figure in parentheses indicates the total number of observations 
Bang. J. Anim. Sci. 2009, 38(1\&2)

\section{Conclusion}

It may be concluded that sheep of BLRI were better performer followed by Coastal, Barind and Jamuna region. Other than BLRI nucleus flock, the reproductive performance in terms of litter size of Jamuna region sheep was comparatively better than the others.

\section{Acknowledgements}

We acknowledge the financial support of GOB funded national project entitled "Conservation and improvement of native sheep through community farming and commercial farming", Bangladesh Livestock Research Institute (BLRI).

\section{Literature Cited}

Geenty, K. G., Young, S. R., Clarke, J. N., Wilson, J. A. 1982. The effects of lamb breed, slaughter age and sex on carcass fat depth and export grade. Templeton Agricultural Research Station, Ministry of Agriculture and Fisheries, Templeton; Ruakura Animal Research Station, Ministry of Agriculture and Fisheries, Hamilton Proceedings of the New Zealand Society of Animal Production. 1984, 44: 227-230

Henson, E. L. 1992. In-situ conservation of livestock and poultry. FAO Animal Production and Health Paper- 99.

Maijala, K. and Oesterberg, S. 1977. Livestock Prod. Sci. 4, 355-377

Rusyad A., Gurawan, B., Hetzel, D. J. S., Barkie, B., Yates, N. G. and Chaniago, T. D. 1985. Comparison of lamb production from indigenous and exotic cross indigenous ewes in Indonesia. Trop. Anim. HIth Prod., 17(3): 127-134.

Turner, H. N. 1978. Prolific sheep breeding plans. International Seminar on Sheep and Wool, Islamabad, Pakistan, Agricultural Research Council; 49-66.

Woolliams, J. A., Gwaze, D. P., Meuwissen, T. H. E., Planchenault, D., Renard, J. P., Thibier, M. and Wagner, H. 1998. Secondary guidelines for development of national farm animal genetic resources management plans. Management of small populations at risk. Initiative for Domestic Animal Diversity (IDAD). FAO, Rome. 